\title{
DEALING WITH DIVERSITY
}

Thematic Interpretation on "Defending Islam"

\author{
Ali Ja'far \\ STAI Al-Anwar Sarang \\ Mohard41@gmail.com
}

\begin{abstract}
Modern Indonesian had featured by two overlapping terms 'Defending Religion' and 'Defending Islam'. Both are similar and popular term during the light of Islamic resurgence in the post-reformation era. As the term emerged publicly, religious discourse and debate concerning on the term are inevitable. The term, problematically, used by the particular group to legitimate numerous political actions, escalated the number of religious blasphemy. Surely, Muslims are obligated to defend Islam, but Islamic teaching also encourages the Muslim to respect communal-pluralistic society. By employing a thematic approach, this paper then argues that the idea of 'defending religion' should be revisited. Based on the occasion of revelation, the collected verses initially considered as an appeal to do "justice" ('adl), fight against the repressive community, persecution, displacement, and any outraged acts. Through tracing the occasion of revelation, this paper also argued that the idea of "defending religion" has also much to do with the idea of "defending diversity" in the context of pluralistic society.
\end{abstract}

Keywords: diversity, defending Islam, thematic exegesis, conservatism.

\begin{abstract}
Abstrak
Indonesia Modern menghadapi dua terma yang saling tumpang tindih. 'membela agama' dan "membela Islam". Kedua terma ini mirip dan popular pada masa kebangkitan Islam pasca-reformasi. Sebagaimana terma ini muncul pada ruang publik, diskursus keagamaan dan perdebadatan mengenai dua terma ini tidak dapat terhindarkan lagi. Terma ini, secara problematis digunakan oleh sekelompok grup yang secara politis digunakan untuk melegitimasi aksi mereka, dan mengangkat berbagai macam kasus penodaan aga,a. Tentu saja, muslim diwajibkan untuk mempertahankan Islam, akan tetapi ajaran Islam juga mengajarkan untuk mendorong keharmonisan dalam masyarakat yang pluralistik. Dengan menerapakan pendekatan tematis, tulisan ini berargumen bahwa ide-ide tentang "membela agama" yang ada dalam alQur'an harus dilihat kembali. Berdasarkan sebab turunya ayat pada tafsir tematik, bahwa ayat yang berkaitan dengan bela "agama" awalnya adalah seruan untuk melaksanakan keadilan ('adl), berjuang melawan masyarakat komunitas yang represif, melawan persekusi, pengusiran, dan perbuatan yang melampui batas. Melalui pelacakan pada sebab turunya ayat, tulisan ini juga berargumen bahwa ide tentang "bela agama" juga berkaitan dengan ide tentang "membela keberagaman" dalam konteks masyarakat plural.
\end{abstract}

Kata kunci: Keberagaman, Bela Islam, Penafsiran tematis, Konservatif 


\section{A. Introduction}

By the end of 2016, Indonesia was shocked by a massive rally in Jakarta demanding the persecution of Basuki Tjahaja Purnama (well known as Ahok). He is a Chinese Christian who was allegedly charged for religious blasphemy following his controversial statement onQS 5:51 ${ }^{1}$. The rally which was mainly mobilized by the FPI (Front Pembela Islam/ Islamic Defender Front) was labeled by its participants as bela agama/ Islam (defending religion/ Islam). This self-labeling is in itself problematic as it could potentially lead to increasing religious sentiments within the relationship between Muslims and Non-Muslims in Indonesia.

Indeed, Indonesian citizens in the post-Suharto regime had been experiencing massive transformation, from civil Islam reformation with a vibrant democratic government to the resurgence and re-emergence of religious militant groups ${ }^{2}$. The transformation in particular marked with the shift of religious authority, revivalism, exclusivism, violence, and the strong persistence of reformist group featured with street justice and - law $^{3}$. Unlike common - street rallies that fight - against corruption, poverty, and economic issues, the current trend of rallies have -embraced primordial issues of religiosity and ethnicity. In addition, this act is by arguing for defending Islam. As Wilson ${ }^{4}$ says, the embrace and elevation of Islam by such an exclusive and conservative Islamic militant groups has been a new feature of Indonesia's post-Suharto democracy.

Both exclusivism and conservatism theologically are not only challenging the state authority and threatening the very foundations of religious life such diversity, but also affected negatively to the pluralistic society of Indonesian Muslim. Indeed, exclusivism is not only the wrong path for a pluralistic society, but also affected the image of good Muslim ${ }^{5}$. Within this study, the resurgence of conservative groups with such truth claim is regarded as the 'antitheses' of 'religious diversity' and unfortunately, these groups also legitimate their acts mainly based on the Qur'an. Religious conservatism had seen by many scholars such as

\footnotetext{
${ }^{1}$ Kate, The Guardian “Jakarta Governor Ahok' blasphemy trial: All you need to know”. accessed in 11 December 2016

${ }^{2}$ Hefner, R. Civil Islam: Muslims and Democratization in Indonesia. New Jersey: Princeton University Press 2000:05.

${ }^{3}$ Jeremy Menchik Islam and Democracy in Indonesia: Tolerance without Liberalism. England: Cambridge Studies in Social Theory of Religion and Politic (2016:173).

${ }^{4}$ Wilson, I. 'Morality Racketeering: Vigilantism and Populist Islamic Militancy in Indonesia', in Between Dissent and Power: the Transformation of Islamic Politics in the Middle East and Asian. Hampshire: Palgrave MacMillan 2014:a

5 Sahiron Syamsuddin: The Qur'an on the Exclusivist Religious Truth Claim: A Ma 'nā-cum-Maghzā Approach and its Application. German: The Lutheran World Federation 2017:99.
} 

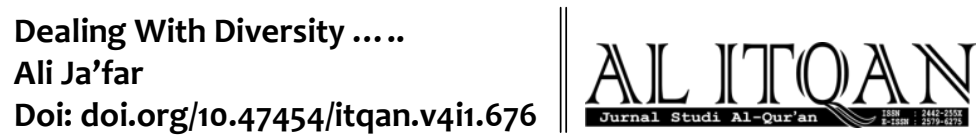

Hunter cited by Halev as an exclusive belief in the transcendental authority. People of this view believe and assume that their religions are the only true and the people differ from them would be considered as simply false ${ }^{6}$. Hence, the conservatism points out that such hierarchical-binary idea of Muslim and non-Muslim, insider and outsider, friend and enemy, Muslim-kafir (infidel) are significantly important. As the idea went out and widespread, Muslim community then became more vulnerable in facing diversity.

This paper then scales up that such turmoil situation was triggered by the conservative ideas based on a particular understanding of the Qur'an. Nevertheless, this paper also recognized that such conservatism has many factors such as politic upheaval and sociological disruption (but that is another issue). Further, as the verses of 'defending religion' were potentially misrepresented and "misused", it is necessary to relook at the paradigmatic chain that leads to unconstructive-harmful interpretation and reconstruct an understanding for respecting religious life and diversity. Therefore, this paper deals with two issues, namely the problem of Qur'anic exegesis in understanding 'defending Islam' and religious diversity. In interpreting religious diversity, scholars like Appadurai and James give a narration that monoreligious community has to rewrite the narration about solidarity and equal citizenship ${ }^{7}$ between and among religious communities. The keyword given to understand this term is social change, which concerns an equal demographic stratification via religion, pluralistic and recognizing the beliefs of others.

As we began to address some problematic interpretation of the term "defending religion" (read: defending Islam), it is helpful to trace the historical term of "defending religion" in contemporary use and unpack the meaning based on thematic exegesis critically. This approach is useful to present the wide picture of the term and see the link that connecting one verse to another verse.

Further, the point of departure of this paper is concerning the idea that religious texts may be interpreted based on contemporary context. This is not only matter of interpretation, but also building a progressive discourse to reckon and appreciate the pluralistic society as the fact of modern context. Saed mentioned that reinterpreting the Qur'anic teaching nowadays is definitely important since today situation may be different from the archaic Arabian context.

\footnotetext{
${ }^{6}$ Jeff Spinner-Halev, Surviving Diversity, Religion and Democratic Citizenship, The Johns Hopkins University Press, 2000

${ }^{7}$ Arjun Appaduarai 2001 “Globalization” Duke University Press, 2001:06
} 
Indeed, the idea such particular interpretation is somehow misleading andinappropriate ${ }^{8}$. This paper then proposed a question of how do the Muslim scholars interpret the term "defending Islam" and how significant the reinterpretation of verses in respecting the idea of religious diversity.

\section{B. Thematic Exegesis and Religious Diversity}

Dealing with the term "defending religion" well-meaning "defending Islam", this paper employs two different strands in understanding the verses; namely thematic approach of the Qur'an and then reconstructing the interpretation based on the idea of respecting diversity. The thematic approach or what so called as (موضوعي/maudhūi) is one of the powerfullens to unpack and undress the specific issues in the Qur'an since it rejuvenates into account the actual problem through deepening the analysis thematically ${ }^{9}$. In addition, thematic interpretation pointed out specific issues as a matter of discourse ${ }^{10}$. The term موضوعي per se was kind of noun passive participle (isim maf'ül/(اسم مفعول) derived from the past tense verb (fi'il mādi - فضع وضع (wadha'ayadha'u) which means to establish, institute, invent, compose and compile and etc ${ }^{11}$. Therefore the closest meaning of موضوعي (iterally is gathering-composing-compiling the subject into one discourse based on a specific theme. Terminologically, موضوعي/maudhūì is an approach to interpret the Qur'an by collecting and gathering the similar verse or based on the specific theme that has similar issues regardless the location or chapters in the Qur'an, time of revelation and the occasions of revelation ("asbāb al-nuzūl") $)^{12}$. Therefore this approach required an explanation not only based on the text and scholar explanations per se, but also on the historical context.

According to al-Farmāwi ${ }^{13}$, there are several important steps in this approach. These areby selecting the specific theme or the issues, gathering-compiling the related verses, organizing the verse based on the time of revelation, the occasion of revelation, considering the prophetic tradition, and the last is analyzing and discussing the related verses comprehensively. In an attempt to grab a wider explanation, this paper was also aware on the

\footnotetext{
${ }^{8}$ Abdullah Saeed, Interpreting The Qur'an Toward a Contemporary Approach. Roudlege, Taylor and Francis Group: $2006: 5$

9 Umar Shihab, Kontextualisasi Al-Quran Kajian Tematik ayat ayat hukum dalam Al-Qur'an. (Jakarta: Penamadani, 2005:3)

${ }^{10}$ Abdul Hayy Al-Farmawiy, Metode Tafsir Maudhu'Idan Cara Penerapanya, ter. Rosihan Anwar (Bandung: Pustaka Setia), 2002:43

11 Mandzur ibnu: Lisanul Arab chapter Nun

12 Abdul Hayy Al-Farmawiy, Metode Tafsir Maudhu'I suatu pengantar, (Jakarta: Raja Grafindo Persada), 1996:38 13 Ibid
}

4 AL-ITQAN,Volume 4, No. 1, 2018 

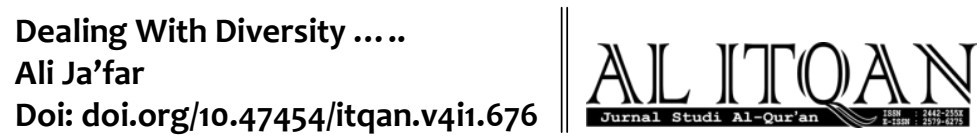

historical context of each the verse and explaining how the classical scholars xplicate and locate the verse based on the surrounding context.

Dealing with thematic interpretation is diversity. This point is significant to understand the pluralistic societies who hold common identity, historical barrier and reunite societies into one strong engagement and citizenship. Nevertheless, the idea about diversity itself had been rooted in Muhammad's life during his prophetic era. Contemporarily there are a lot of scholars linked the Qur'anic exegesis with diversity ideas. Yet, focusing on the thematic exegesis of 'defending religion' and in the context of Indonesia is still rare. As a contemporary analysis, this paper employs the idea from Bikhu Parekh ${ }^{14}$ idea on the collective right of multicultural-pluralistic society. He mentioned that within communal life, multicultural society needs to uphold their collective identity as a common barrier. The barrier may come from shared historical values or long-term interest in surviving the most valuable aspect of their communal life. In this point, Halev ${ }^{15}$ added that diversity is multiple dialogs between and among the group with different multiple point of view. Hence, still in the context of pluralistic society, a person may have the right to convey his/her idea publicly as part of the individual right and also respect the other right appropriately.

\section{Occasion of Revelation}

The terms 'Defending religion' or 'Defending Islam' per se do not occur explicitly in the Qur'an and there is no sustained discussion of its origin. However, the people who do the act of "Defending religion" cited the related-resemblance verses to legitimate the action. As a statement by Alwi Alatas ${ }^{16}$ who stated that the root of "Defending Islam" is (QS 61:14) that obligate a Muslim to defend their religion. Indeed, as he continued that the obligation was God's mandatory instead of the political act or any religious-political sentiment. The obligation as he stated is also to defend the Qur'an Al-Ma'idah (5:51) that warns Muslims not to take Jews or Christians as awliy $\bar{a}^{6}$, which commonly translated as friends, allies, guardians, or helpers. However, as the act went by, the cited verses to defend religion are likely having phrases such as “'Tanşurū Allāh”, “anșar Allāh”, “yanșurū Allāh”, yanșurū hu” The phrases are loosely translated as "to give victory of Allah, to save Allah, to make triumph for Allah".

\footnotetext{
14 Bikhu Parekh, Rethinking Multiculturalism; Cultural Diversity and Political Theory. Harvard University Press, 2002: 322

15 Jeff Spinner-Halev, Surviving Diversity, Religion and Democratic Citizenship The Johns Hopkins University Press, 2000

${ }^{16}$ Alwi Alatas " Perlukan Membela Agama Islam? Posted in Hidayatullah.com. accessed 09 September 2018.
} 
The phrase consists of two root words with consonant $n / s / r$ as verb and Allah as a proper noun.

The idea of 'defending Allah' in modern practice then developed and translated into the idea of 'defending religion' and 'defending Islam'. This paper then considers the practice as a phenomenon of overlapping understanding in which the people gather the words "Allah", "Islam" and "religion" into one package. The unintended consequence of this overlapping term is the superiority of Muslim over another religious group socially.

Based on this phenomenon, this paper then gathered some phrases as a term in the related verses. By using the abovementioned root words of $\mathrm{n} / \mathrm{s} / \mathrm{r}$ and the help of 'Qur'an digital', this paper then found several verses, they are:

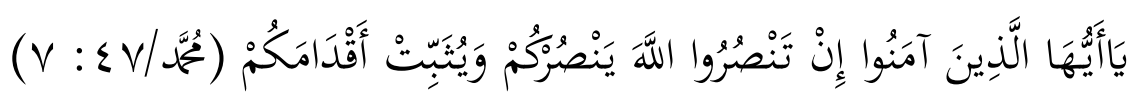

ye who believe! If ye help Allah, He will help you and will make your foothold firm. (QS. Muhammad/47: 7) (En. Pictall, transliteration.org) ${ }^{17}$.

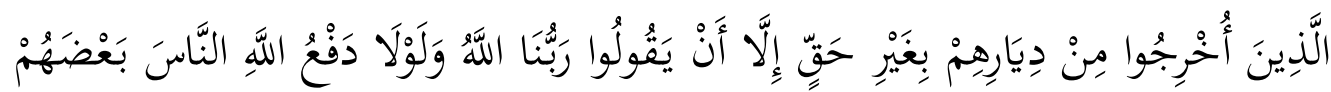

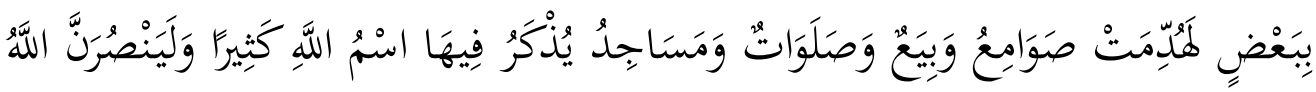

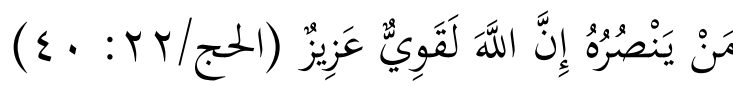

(Those who have been driven from their homes unjustly only because they said: Our Lord is Allah - For had it not been for Allah's repelling some men by means of others, cloisters and churches and oratories and mosques, wherein the name of Allah is oft mentioned, would assuredly have been pulled down. Verily Allah helpeth one who helpeth Him. Lo! Allah is Strong,. (QS. al-Hajj/22: 40)

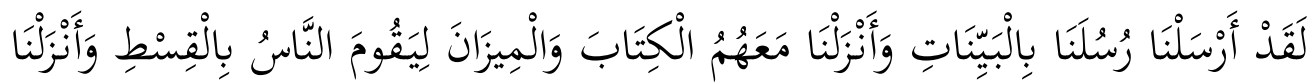

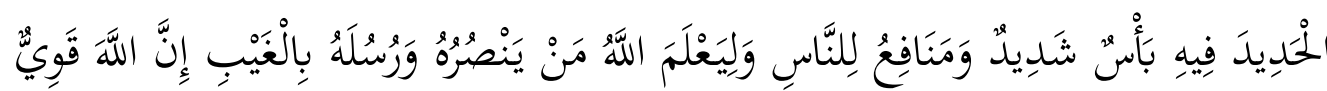

$$
\begin{aligned}
& \text { عَرِيزٌ (الحديد/OV: }
\end{aligned}
$$

We verily sent Our messengers with clear proofs, and revealed with them the Scripture and the Balance, that mankind may observe right measure; and He revealed iron, wherein is mighty power and (many) uses for mankind, and that Allah may know him who helpeth Him and His messengers, though unseen. Lo! Allah is Strong, Almighty. (QS. al-Hadīd/57: 25) 


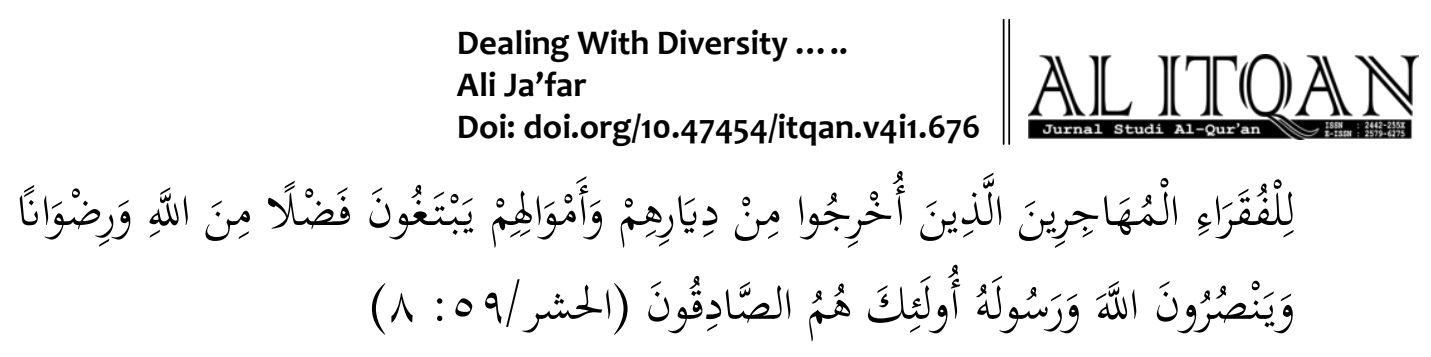

(And (it is) for the poor fugitives who have been driven out from their homes and their belongings, who seek bounty from Allah and help Allah and His messenger. They are the loyal).. (QS. al-Hasyr/59: 8) ${ }^{18}$

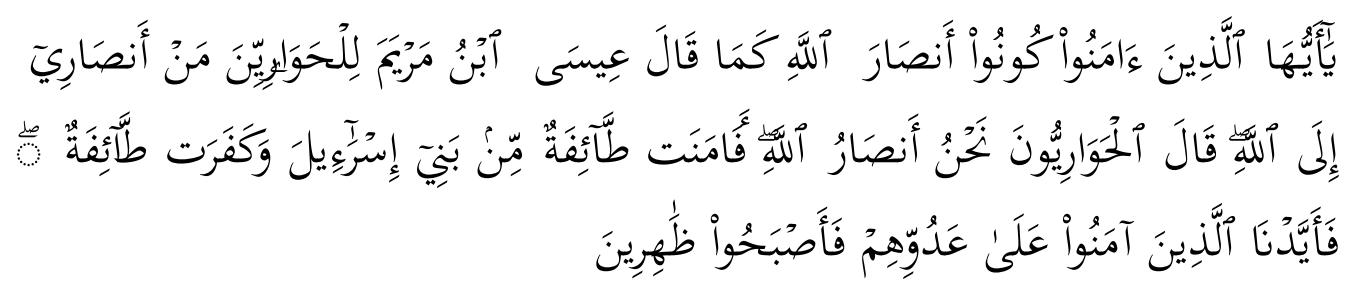

"ye who believe! Be Allah's helpers, even as Jesus son of Mary said unto the disciples: Who are my helpers for Allah ? They said: We are Allah's helpers. And a party of the Children of Israel believed while a party disbelieved. Then We strengthened those who believed against their foe, and they became the uppermost". (QS As-Saf/61:14)

Focusing on the specific term, the abovementioned will be discussed according to the occasion of revelation, the type of the chapter and then followed with the relation between one verse to another.

First is QS: Muhammad/47:7 that known also as Al-Qitāl or Allazîna Kafarū. The type of this chapter is Madāniyah accordingtolbn Abbās ${ }^{19}$. According to Qurthubîi ${ }^{20}$, the revelation of this chapter is based on the difficult situation-condition in which the nonMuslim Mecca (kufār Makkah) had strongly persecuted and also displaced the prophet and his companions from their own homeland. In addition, $\mathrm{Sihab}^{21}$ mentioned that scholars agree the verses on this chapter emphasize defending the right and preventing the persecution. This verse is the early verse that obligates Muslim to do qitâl against the non-believer Mecca. Therefore, the designation of this chapter is Al-Qitâl. This chapter also implies an appeal to fight against the outrage unbeliever, to maintain the religion and to fight against persecution. The redaction is

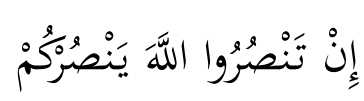

\footnotetext{
${ }^{18}$ Kementerian Agama Republik Indonesia, Al-Qur'an Tajwid dan Terjemahnya, (Bandung: Sygma, 2010). 337546.

19 Ahmad Al-Anshāri Al-Qurthubī "Al-Jāmi Al-Ahkāmi Al-Qur'an" (Riyādh-Dār Al-Alam Alkutum) 8th edition, vol:16 2003:223

20 Ahmad Al-Anshāri Al-Qurthubī "Al-Jāmi Al-Ahkāmi Al-Qur'an" (Riyādh-Dār Al-Alam Alkutum) $8^{\text {th }}$ edition, vol:16 2003:223

21 Quraish Sihab, “Tafsîr Al-Misbāh: Pesan, Kesan dan Keserasian Al-Quran” (Jakarta: Lentera Hati) second edition, Vol 12 2009: 438
} 


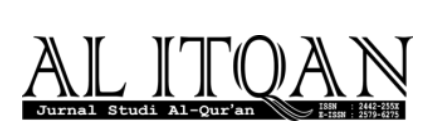

\section{Dealing With Diversity ..... \\ Ali Ja'far \\ Doi: doi.org/10.47454/itqan.v4i1.676}

Translated as "Jika kamumenolong (agama) Allah niscaya Dia akanmenolongmu”

English translation "If you Support Allah He will support you"

Second is (QS. al-Hajj/22: 40), this chapter is Makiyyah accordingtolbn Abbās and Mujahid, but Madāniyah according to other ulama ${ }^{22}$. Thus, the chapter called Mukhathalath(the mixed chapter in the revelation). The mufassirûn (tafsîr scholars) stated that the nonbeliever of Mecca continuously persecuted the prophet's companion such as beating and oppressing. The companions reported to the prophet and he said: " (be " (bبرو إني لم أومر بالقتال passion, I haven't obligated to fight). Then the prophet Muhammad migrated to Medina and the verse revealed. This is the first verse allowing the prophet to fight against the nonbeliever. According to Mujāhid, this verse revealed to the Muslim Mecca who prohibited by the non-believer to migrate in Medina in the early of Islam ${ }^{23}$.

The redaction is

$$
\text { وَلَيْنْصُرَنَّ اللَّهُ مَنْ يَنْصُوهُ }
$$

"Allah pastiakanmenolong orang-orang yang menolong (agama)-Nya"- "Verily Allah helpeth one who helpeth Him"

Third is (QS. al-Hadīd/57: 25), a chapter that according to Ibn Abbās ${ }^{24}$ and the majority (jumhur) ${ }^{25}$ is Madāniyyah. Ibn Abbās mentioned that this chapter is explaining that God knows everything and any human attention. This verse revealed to inform the Muslim that Allah knows their intention when they help Allah and His prophet ${ }^{26}$. The redaction is

$$
\text { وَلِيَعْلَمَ اللَّهُ مَنْ يَنْصُوهُ وَرُسُعلَهُ }
$$

Allah mengetahuisiapa yang menolong (agama)-Nya dan rasul-rasul-Nya and that Allah may know him who helpeth Him and His messengers

Fourth, (QS. al-Hasyr/59: 8) well known also as Banî an-Nadhîr. This chapter is Madaniyyah according to the majority ${ }^{27}$. The occasion of revelation according to many scholars: when the prophet arrived in Medina, he became the leader of Arabian tribes, Christian community, and Jewish clan. In Medina, the prophet has a pledge between the prophet and the tribes in Medina, one of them is Banî an-Nadhîr (Jewish clan). The pledge is

\footnotetext{
22 Ibid, vol 12, 2003:1

${ }^{23}$ Abî Muhammad Al-Husain bin Mas'ûd Al-Baghowî: "Tafsîr Al-Baghowi Ma'âlim tanzîl” (Bairut: Dâr Taibâh), 516H Vol 5: 389.

${ }^{24}$ Muhammad Jamil "Hasiyah Alshowi fi tafsir al-jalalain" (Lebanon: Dar Ibn Asosoh) 2005:217

${ }^{25}$ Ahmad Al-Anshāri Al-Qurthubī "Al-Jāmi Al-Ahkāmi Al-Qur'an" (Riyādh-Dār Al-Alam Alkutum) 8th edition, vol:17 2003:235

${ }^{26} \mathrm{Ibid}$, Vol 8: 31

${ }^{27}$ Ibid, vol:18, 2003:01
}

8 AL-ITQAN,Volume 4, No. 1, 2018 

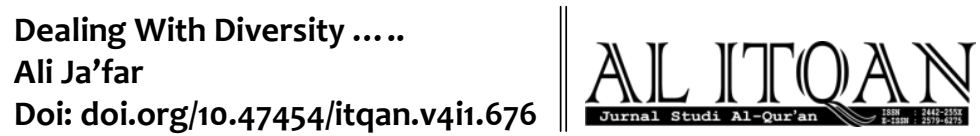

an agreement to live peacefully. After the battle of Badar, Banî an- Nadhîrshowed hostility against the prophet and they allied with the non-believer of Quraish to fight against the prophet. They were also spying the activity of the Muslim community in Medina. The prophet then exiled them out of Medina. They brought their belonging but also leave behind their property. ${ }^{28}$ The redaction is

$$
\text { وَيَنْصُوُونَ اللَََّ وَرَسُولَهُ }
$$

(demi) menolong (agama) Allah dan Rasul-Nya (and help Allah and His messenger)

Fifth is(QS As-Saf/61:14) well known as "Īsā" or "Al-Hawāriyyūn". This chapter is Madaniyyah according to majority and Makiyyah according to Ibn Abbās ${ }^{29}$. After the battle of Badar, It is narrated that: the verse revealed to inform the companion of the prophet Muhammad that Allah appreciates the Muslims who fight for defending Allah, likewise the Hawâriyîn (the follower of Isa) who defend for Allah. ${ }^{30}$ The redaction is

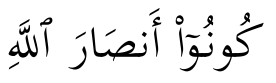

Jadilah kamu penolong (Agama) Allah- Be Allah's helpers

From the explanation of related verses above, occasion of revelation, first, it can be seen that the phrase 'Tanşurū Allāh' translated in English as 'help Allah' and translated in Bahasa as "menolong (agama) Allah". The shifting translation from "helping Allah" to "helping (religion) of Allah" in Bahasa, and commonly used by the mob as "helping Islam" is an overlapping term. Meaning, the people commonly use "Allah" and "religion of Allah" into one package. Secondly, most of the chapters of the verses are Madāniyyah. A categorization marked by the emigration of the prophet to Medina after long persecution in his own homeland, Mecca. Third based on the occasion of revelation it is mentioned the obligation to defending Allah' 'religion' from non-believer, an obligation to fight against any persecution, displacements and any inhuman acts and the fighting is allowed only for certain reasons, such as against the group that breaking the pledge of communal life, betrayal, against inhumanoutraged practice, protecting the basic right of religious community in performing their belief. Otherwise, based on the occasion of revelation, the obligation of helping, well-meaning

\footnotetext{
28 Abî Muhammad Al-Husain bin Mas'ûd Al-Baghowî: "Tafsîr Al-Baghowi Ma'âlim tanzîl” (Bairut: Dâr Taibâh), 516H Vol 8: 67.

${ }^{29}$ Ibid, vol: 18, 2003:77

${ }^{30}$ Ibid, vol 8:107
} 

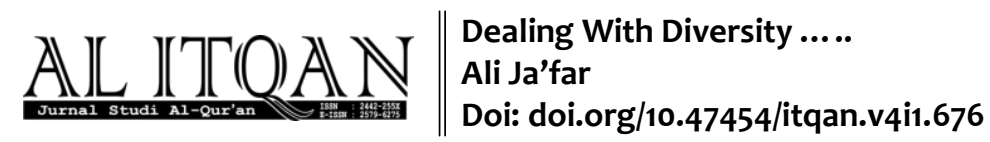

defending Allah religion through certain actions of war, jihâd and etc, are not clearly mentioned in the peaceful religious community.

\section{Classical Scholars' View on 'Defending religion'}

Concerning on the problematic idea of 'Defending religion", this paper also considering classical scholars views as an account of discussion: Sayyid Quthb in his book entitled Fi Zhilâlil Qur'an explained the (QS Muhammad: 07) as an obligation of doing jīhâd. He stated that the clause 'in tanşurū Allāh' has an implication of doing jihâd for Allah. Indeed, Sayyid Quthb linked the phrase 'in tanşurū Allāh' with the related verse of QS, Muhammad:07

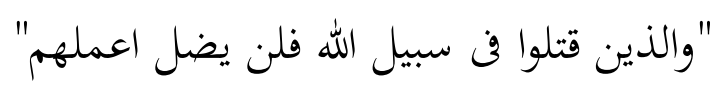

"And those who are slain in the way of Allah, He rendereth not their action vain" (Qur'an English translation by Pictall).

Sayyid Quthb noted that the notion of nşr (help) and qutilû (slain) was to Allah. Indeed, he also noted that there is no action accepted for jihad and qital(war) but only because of Allah and defending the Syariah of Allah. ${ }^{31}$ Interpreting the meaning of $n s ̧ r$ (help) as an action of jihad had also proposed by Qurthubī. He mentioned that the action of tanşurū has much to do with the narration of occasion of revelation in which the non-believer of Mecca continuously persecuted the prophet and his companions. He linked the verse "QS Muhammad: 07" with the previous verses about qitâl (battle) in the realm of Allah, such as QS 47:01 saying that "Those who disbelieve and turn (men) from the way of Allah. He rendereth their actions vain ${ }^{, 32}$. In addition, he said that the term tanşurū Allāh in practice is by defending His prophet, both defending Allah and prophet has one meaning ${ }^{33}$.

Further At-Thabâri also explained the verse of QSal-Hajj/22: 40 as Allah will help those who help His (religion) in the battle and those who struggle for the glory of Allah against His enemies. Indeed, the meaning of helping Allah is by jihâd (an effort to do something either by war or anything else) and raising the glory of His syariah. ${ }^{34}$ Likewise Thabâri, Qurthubī also mentioned the verse is linked with the condition of the Prophet and his companions that continuously persecuted by the non-believers of Mecca. The outraged acts

\footnotetext{
${ }^{31}$ Sayyid Quthb, Fi Zilalil Qur'an, (Jakarta: Gema Insani, 2004) hlm 352

${ }^{32}$ Ahmad Al-Anshāri Al-Qurthubī “Al-Jāmi Al-Ahkāmi Al-Qur'an" (Riyādh-Dār Al-Alam Alkutum) $8^{\text {th }}$ edition, vol:16 2003:223

33 Ibid

${ }^{34}$ At-Thabari, Jami' al Bayan fi Ta’wil al-Qur'an, (Muasasah ar-Risalah: 2000) page 651
} 

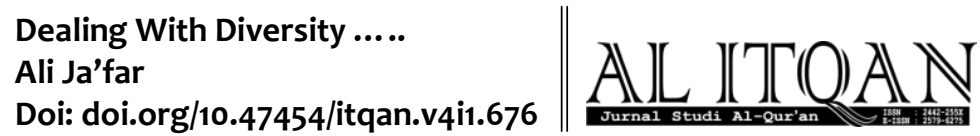

and persecution had threatened the Muslim community in Mecca ${ }^{35}$. The outraged acts and persecution had threatened the Muslim community in Mecca . From the explanation of QS 47:07 and QS, 22:40, it can be seen that classical scholars seem to agree that the meaning of 'helping Allah' is by defending Islam, Muslim, and Syariah in particular. However, the act of 'defending' also linked with the condition of persecution over the prophet and his companions when he was in Mecca.

Unlike QS: Muhammad/47: 07 and al-Hajj/22:40, QS. The term “yanșurū" in the alHasyr (59) : 8 has a different occasion of revelation. The verse linked about $f a$ ' $i$ (spoil of war) that was also for the poor people displaced from their home and migrated to Medina as the refuge. According to Ibnu Kasīìr ${ }^{36}$ and 'Alī al-Șābūnīin ${ }^{37}$, this verse explained about the condition of deprived people, exiled from their home, underprivileged within the community, and crossing the town as a refugee. According to the majority of scholars, this group is the first group migrated to Medina. These groups of people were fighting against the brutal community in Mecca and in seeking the bounty from Allah. They were exiled from their home and migrate to Medina as a refuge. As the Qur'an mentions that what they did was honorable according to Allah, they are the Muhäjirin. Further, Ibnu Kasīir also linked the verse with the occasion of revelation in which Banî an-Nadhīr, Jews clan in Medina, had broken the pledge and was in alliance with non-believer Mecca to fight against the prophet. Previously, it is narrated that before the coming of the Prophet, Jews tribes such as Banî anNadhīr,Bani Qainuqa' and Bani Quraizhah were used to be in clash with the Arab tribes such as Aus and Khazraj. After the prophet migrated to Medina, became the leader and won in the battle of Badar, Banî an-Nadhîr was in alliance with non-believer Quraish to slay the prophet, spying and betraying the Muslim in Medina ${ }^{38}$. Considering Banî an-Nadhîr as a malicious clan, the prophet then exiled them out of Medina; they went out of Medina and left behind their ruined property.

Further, although QS. al-Hasyr (59) and the two previous verses have different occasions of revelation, but both of them have something in common; that is an obligation to fight for Allah, denounce betrayal for a peaceful life, defend Islam and protect Muslim

\footnotetext{
35 Ahmad Al-Anshāri Al-Qurthubī, "Al-Jāmi Al-Ahkāmi Al-Qur'an" (Riyādh-Dār Al-Alam Alkutum) 8th edition, vol:18 2003:01

${ }^{36}$ Ibnu Katsir, Tafsir al-Qur'an al-Adzim, terj. M. Abdul Ghoffar (Bogor: Pustaka Imam Syafi'i, 2005), hlm. $111-112$ 37 Muhammad Ali Ash-Shabuni, Shafwah al-Tafasir, (Beirut: Dar al-Qur'an al-Karim), hlm. 352.

${ }^{38}$ Shalabi, Ali Muhammad. "Ghozâwatu ar-Rasul. Durus wa I'bar wa fawâid" (Kairo: Muassasah Iqra') 2007:93.
} 


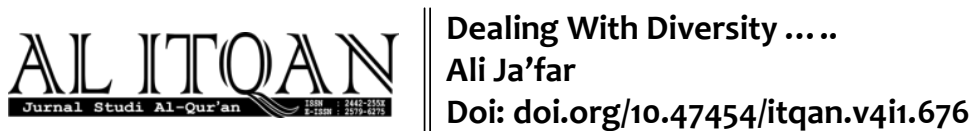

community. This obligation also encouraged all Muslim individually and communally to defending Allah and His prophet by means of jihād and defending Muslim from any persecution, discrimination and the excess from the outraged acts.

Similar to the abovementioned verses is QS. al-Hadid (57) : 25

$$
\text { وَلِيَعْلَمَ اللَّهُ مَنْ يَنْصُرهُ وَرُسُعلَهُ بِالْغَيْبِ }
$$

Meaning "and that Allah may know him who helpeth Him and His messengers, though unseen. Lo! Allah is Strong"

and (QS As-Saf/61:14) narrated"

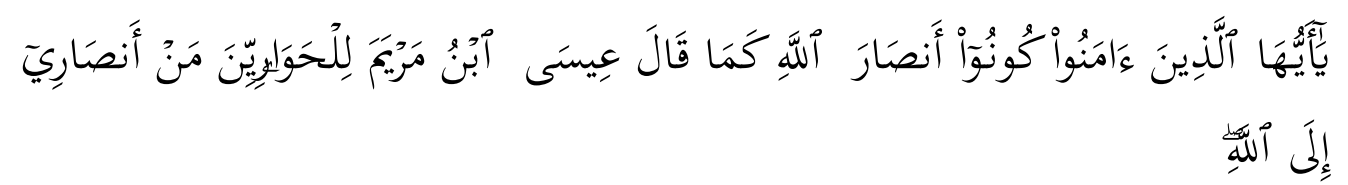

"ye who believe! Be Allah's helpers, even as Jesus son of Mary said unto the disciples: Who are my helpers for Allah? They said: We are Allah's helpers"

The pinpoint of these verses are an encouragement for Muslim to defend Allah and as the declaration that the prophet Muhammad brings about the right promise. These are by narrating the glory of Muslim in the war of Badar and the story of Hawäriyin (the follower of Isa) as those who help Allah. Indeed, this verse also pointed out that Allah will help those who fight for the glory of Allah although Allah needs no help from a human being. Qurthubī in this regard explained that these verses have much to do with the prophet Muhammad who brings about clear evidence (البينت) on the glory of Allah. That Allah obligated human being to do jihâd for Allah was solely to examine the faith of Muslim. ${ }^{39}$ Further, according to Wahbah Zuhaili, the meaning of jihâd is a maximum effort to defend religion by any means from the violation of the non-believers.. ${ }^{40}$

From the above interpretation, classical scholars have many things in common regarding the term of 'Defending Allah' or 'Defending Islam' and when the jihad or qitâl were allowed. First 'defending Allah' or 'Islam' is an obligation for Muslim endangered by a non-believer. The mufassirun were linked their interpretation with the occasion of revelation in which the Muslim Mecca were persecuted by non-believer repressive community as in QS

\footnotetext{
${ }^{39}$ Ibnu Katsir, Tafsir al-Qur'an al-Adzim, terj. M. Abdul Ghoffar (Bogor: Pustaka Imam Syafi'i, 2005), hlm. 6465.

${ }^{40}$ Mukharis, "Jihad dan Terorisme", dalam Sahiron Syamsuddin (editor), Al-Qur'an dan Isu-Isu Kontemporer, (Yogyakarta: Elsaq Press, 2011), hlm. 95.
} 

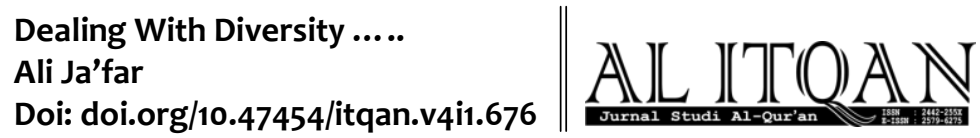

Muhammad, 47:7 and Al-Hajj 22:40. Therefore the verse is in an appeal for Muslim to do qitāl for Allah.

Secondly, the act of defending Islam is allowed when the non-believers were in alliance to fight against Islam, breaking the pledge for a peaceful life with the Muslim community. Such as in the case of Bani Nadzir that made an agreement to live peacefully with the Muslim community. However then, they betrayed the agreement and revolt against the Muslim. The significance of the verse is that Muslim also obligated to fight against a malicious community that endangers the Muslim. The spoil of war is for those who had been displaced from their home and migrate to Medina as a refuge. The third is about encouragement to 'defend Allah' as in QS. Al-Hadid (57): 25. The scholars have similar views that the verse is about a narrative story about the prophet and his companion. As it is narrative, the Muslim may take a lesson that Allah will help those who 'defend Allah' and His prophet.

\section{E. The Verses in Indonesian Context}

From the time and occasion of revelation, prophetic tradition, and classical scholars' view on the thematic verses above; it may be noted that the term "defending Islam" was strongly tied to a historical event in the prophetic era. The term, historically, refers to an unstable condition where the Muslim faced discrimination and persecution in Mecca, betrayal in Medina, and battle after battle. The continuous violent against the first Muslims and their precarious situation after the emigration to Medina, Allah revealed the verse of jihad by allowing Muslim to do war and to slay (A. qitâl) in term of 'defending Allah".

However, the term thematically showed about different stage-level of 'defending Allah' and His religion, Islam. Surely, Allah obligated the Muslim to do "defend" for Him, but according to the verses QS 47:7 and QS 22:40 is in the certain categories, such as slaying (A. qitâl) is only in the specific cases. Further, the case of exiling Jewish clans is in other cases too, the depiction in QS 59:8, clearly prompted the Muslim to avoid betrayal. In addition, the meaning of "helping Allah" is also about encouragement for Muslim to defend Allah likewise the follower of İsa did as mentioned in QS 57:25. Thus, the idea of defending Allah was still tied to certain conditions where the Muslims live in. Thus, the significant meaning of "helping Allah" in the age of the prophet had experienced a diachronic process and it was changed over time of prophet-hood. 
Further, to reinterpret the verses thematically and based on diversity view, this paper then looks at the depiction of communities during the era of early prophethood. Tabari explained that the population of Muslim in Medina (Ancient Arabic. "Yathrib") during the early Islam was still a minority and low in number. Unlike Mecca that predominantly inhabited by pagan Arab, Medina inhabited by plural societies around the Arabian Peninsula. Medina, geographically, is the hub for the economic life of Arab. Many traders, merchants, religious leaders, go around and inhabited the city. Among of them are Jewish clans such as Bani Qainuqa', Bani Nadhir and Bani Quraidhah, Arab tribes such as Aus and Khazraj, Christian community, and a small number of pagans such as sābi'ūn ${ }^{41}$ and etc. As the Arab tribes, mostly Aus and Khazraj, and Jewish clans were often in conflict, the prophet Muhammad together with the religious leaders then established what so called as Medina charter (A. şahîfat al-madīnah), a pledge that tied all medina societies into one engaged citizen (A. ummah.). They shared citizenship values, but still maintained their boundaries and identities. From this depiction, it can be seen that Medina during the early age of Islam is kind of pluralistic city with diverse communities. All religious communities are living side aside without any serious grudge, the conflict happened shortly after the betrayal of Jews community. Therefore, if we pay attention to the occasion of revelation and the chronological order of Q 47:7 and such verses as Q 22:40, and Q 57:25, and Q 59:8, we will find that the idea of 'defending religion' was allowed in certain cases, but 'defending religion' through certain acts in the peaceful and pluralistic society may be avoided.

Taking a lesson from the early Muslim in Medina where the prophet Muhammad became a leader of pluralistic society, this paper argues that community in the prophetic age also bears a change socially, culturally and religiously in which the demography, and topography shows about equal citizenship via religion. Further, this paper also finds similarities between the Muslim in Medina in the past and Muslim in Indonesia in the present. Similar to Medina in the early age of Islam, Indonesian citizens bear common historicalcultural barriers. Regardless the religion then, all Indonesian citizens are equal and tied by one single national motto of unity in diversity (Snkrt. Bhineka Tunggal Ika). This foundation emphasized that all citizens should respect other religions and cultures as one notion and maintaining religious diversity.

\footnotetext{
${ }^{41}$ At-Thabari, Jami' al Bayan fi Ta'wil al-Qur'an, (Muasasah ar-Risalah: 2000) vol. 2, 35.
} 

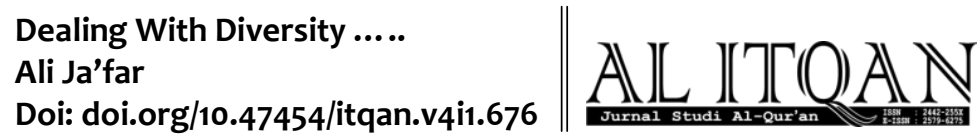

As the idea of unity in diversity was perhaps the most significant promise in the context of Indonesia, the Qur'an also offers the idea of respecting religious diversity. By tracing the idea of 'defending religion'" in the abovementioned verses, this paper argues that the practice of 'defending religion' will always change over timedue to the surrounded situation and the communities. The Qur'an obligated the Muslim to do defense in the context of repressive communities, overcome persecution and discrimination. Nevertheless, the Qur'an also encouraged the Muslim to maintain social relationships in the context of peaceful societies. Nowadays, the emergence of a particular group for 'defending religion' by doing various intolerant actions has destroyed the good image of Muslim community in Indonesia. Therefore this paper insists that any kind of misbehave, intolerance act, and trial by a mob in practice had ruined the idea of "justice" ( $a d l$ ) as the main idea of 'defending religion'.

\section{F. Concluding Remark}

Along with modern-plural society where the encounter between Muslim and other religions had created vibrant pluralistic societies, Indonesian Muslim has been experiencing the emergence of religious exclusivism that brings about misbehave and social conflict. Unfortunately, as the idea widely spread, it also affected the idea of "defending Allah" as a notorious verse".

Based on the thematic interpretation of Q 47:7, Q 22:40, Q 57:25, and Q 59:8 it can be said that the main idea of 'defending Allah' is establishing justice ("adl') between and among societies. The gathered verses mentioned above are about jihad and qital (war), as the Muslim experienced persecution in Mecca. The Muslims in Medina have a different experience and therefore the act of 'defending Allah' is through peaceful acts. As an effort to maintain diversity, Indonesian Muslim may take Muhammad's life (PBUH) as an example of maintaining social relation, showing the image of good Muslim and encouraging the Muslim to do justice toward the other community. 


\section{BIBLIOGRAPHY}

Ahmad Al-Anshāri Al-Qurthubī, "Al-Jāmi Al-Ahkāmi Al-Qur'an” (Riyādh-Dār Al-Alam Alkutum) $8^{\text {th }}$ edition, vol:16 2003:223

Alwi Alatas, “ Perlukan Membela Agama Islam? Posted in Hidayatullah.com. accessed 09 September 2018.

Appadurai, Arjun, ed. 2001. Globalization. Durham: Duke University Press

Ash-Shabuni, Muhammaad Ali. Shafwah al-Tafasir. Dar al-Qur'an al-Karim : Beirut.

At-Thabari, Jami' al Bayan fi Ta'wil al-Qur'an. Muasasah al-Muasirah: 2000.

Bikhu Parekh, 'Rethinking Multiculturalism; Cultural Diversity and Political Theory'. Harvard University Press, 2002: 322

Esack, Farid, “Qur’ān, Liberation, and Pluralism: An Islamic Perspective of Interreligious Solidarity against Oppression”. Oxford: Oneworld. 1998.

Hefner, R. Civil Islam: Muslims and Democratization in Indonesia. New Jersey: Princeton University Press 2000:05.

Ismā'īl ibn Kathīr, Tafsīr al-Qur'ān al- 'Azhìm, vol. 1 (Cairo: al-Fārūq al-hadītha, 2000)

Ismā‘̄̄l, Ibnu Katsir, Tafsir al-Qur’an al-Adzim, terj. M. Abdul Ghoffar (Bogor: Pustaka Imam Syafi'i, 2005)

Jeff Spinner-Halev, Surviving Diversity, Religion and Democratic Citizenship, The Johns Hopkins University Press, 2000.

Jeremy Menchik, Islam and Democracy in Indonesia: Tolerance without Liberalism.

England: Cambridge Studies in Social Theory of Religion and Politic (2016:173 ).

Kate, The Guardian “Jakarta Governor Ahok' blasphemy trial: All you need to know". accessed in 11 December 2016.

Katsīr, Ibn., Tafsīr Ibn Katsīr. Bairūt: Dār al Fikr. 1997.

Kementerian Agama Republik Indonesia, Al-Qur'an Tajwid dan Terjemahnya, (Bandung: Sygma, 2010). 337-546

Ma'arif, Ahmad Syafi'i, 2012. Politik Identitas dan Masa Depan Pluralisme Kita Jakarta: Democracy Project. 

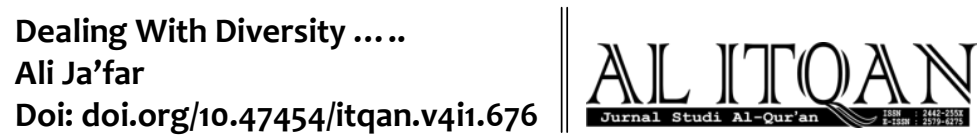

Manzūr, Ibn. 2008. Lisān al- 'Arab. Bairūt: Dār S adr.

Muhammad Jamil “Hasiyah Alshowi fi tafsir al-jalalain” (Lebanon: Dar Ibn Asosoh) 2005

Mukharis, “Jihad dan Terorisme”, dalam Sahiron Syamsuddin (editor), Al-Qur'an dan Isu-Isu Kontemporer, (Yogyakarta: Elsaq Press, 2011), hlm.

Mukharis. 2011. Jihad dan Terorisme. dalam Sahiron Syamsyuddin (editor). Elasaq Press:

Pictall, Qur'an-English translation. Translation.org

Quraish Sihab, “Tafsîr Al-Misbāh: Pesan, Kesan dan Keserasian Al-Quran” (Jakarta:

Lentera Hati) second edition, Vol 12 2009: 438

Qutb, Sayid, 1995. Tafsīr fì zhilāli al-Qur'ān . Beirut: Dār al-Syurūq.

Quthb, Sayyid. 2004. Tafsir Fi Zilalil Qur'an. Gema Insani: Jakarta.

Saeed, Abdullah, 2006. Interpreting the Quran towards a contemporary approach. New York: British Library Cataloguing in Publication Data.

Saeed, Abdullah, 2014. Reading the Qur'ān in the Twenty-first Century: A Contextualist Approach. London dan New York: Routledge.

Sahiron Syamsuddin: The Qur'an on the Exclusivist Religious Truth Claim: A Ma'nā-cumMaghzā Approach and its Application. German: The Lutheran World Federation 2017:99.

\section{Web source}

Wilson, I. 'Morality Racketeering: Vigilantism and Populist Islamic Militancy in Indonesia', in Between Dissent and Power: the Transformation of Islamic Politics in the Middle East and Asian. Hampshire: Palgrave MacMillan 2014. 


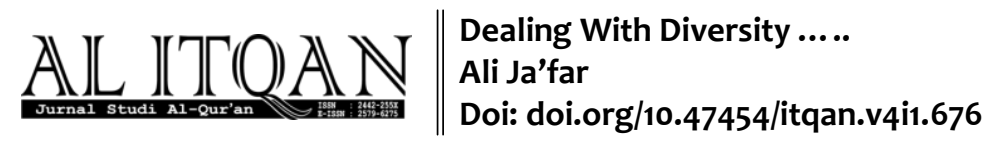

18 AL-ITQAN,Volume 4, No. 1, 2018 